\title{
Polygamy and Muslim Women in Contemporary Indonesian Literature
}

\author{
Wajiran \\ Universitas Ahmad Dahlan, Indonesia \\ E-mail:wajiran79@gmail.com
}

\begin{abstract}
This paper will examine the ways in which polygamy is addressed in contemporary Indonesian literature. The literature that will be analysed is that published after the reformation era, whereby new freedoms have encouraged many Muslim writers to raise this controversial issue. This paper will apply feminist theory especially that of the Muslim feminist Amina Wadud. Furthermore, in order to understand the contextuality of the works, a cultural materialist approach is also applied. There are some Indonesian writers who overtly depict polygamy in their literature, such as Habiburrahman El Shirazy and Alfina Dewi. Although they are all Muslims they have different perspectives in presenting the issue of polygamy in their works. These differences reflect Indonesian Islamic society where polygamy is controversial. Some Muslims accept polygamy as Islamic teaching but others do not.
\end{abstract}

Keywords: muslim women; literature; polygamy; patriarchy; ideology; reformation era; contemporary Indonesian literature

\section{INTRODUCTION}

The reformation era began when the authoritarian President Suharto stepped down from his position in May 1998. This era is well known as the era of openness whereby everyone can express their ideas freely. This era of freedom of speech and expression occurred in every aspect of life including Indonesian literature. There are many contemporary Indonesian literary works that deal with controversial issues, such as sex, women's bodies and polygamy.

The foremost writer who dealt with sexuality and the human body is Ayu Utami. Her controversial novel Saman, published in 1998, is regarded as a pioneer in this kind of freedom of speech and expression in Indonesian literature (Aveling). This kind of literature in turn also influenced Muslim writers to express their ideas through their literature (Hellwig; Ismah). Muslim writers such as Habiburrahman El Shirazy, Alvina Dewi and Abidah El Khalieqy wrote works dealing with women's freedom of expression and polygamy.
This study is intended to reveal the dynamic of polygamy issues in Indonesian literature. Recent Indonesian novels that deal with polygamy include Ayat-Ayat Cinta (The Verse of Love, 2004) and Namaku Naura (My Name is Naura, 2012). Of these, only Namaku Naura (henceforth NN) takes polygamy as its central theme. Therefore, NN will be the main focus of this study. This novel was written by a female writer who supports polygamy. The main character is a female and her position is as the second wife.

The researcher decides to choose these two novels as the research object because these two writers are Muslims. Both of them graduated from pesantren. So this is an interesting idea to see how their ideological background reflected in their literary works. Although they have different view on polygamy, but they have the same idea that polygamy is acceptable in Islam.

As a new writer, Alfina Dewi's work is not so popular as El Shirazy's. NN is Dewi's first novel. 
Although NN is not as popular as AAC, this work gets many attentions from readers. This can be seen from the public discussion especially in social media dealing with the novel. We can also easily find it in google that there are many people who write a sinopsis or review on this novel.

This study will reveal the relationship between social dynamic and Indonesian literature. How do Muslim writers depict Muslim women and how they represent the issue of polygamy in their works? Do they support or reject polygamy as Islamic teaching? To understand the relationship between Indonesian literature and its society this study will begin by presenting the discourse of polygamy in Indonesian society.

$$
* * * * *
$$

The feminist reading that is applied in this study draws on Muslim feminism as proposed by the American, Amina Wadud. Wadud is a professor of Islamic Studies at Virginia Commonwealth University. She is regarded as the most influential American Muslim woman because of her academic achievement and engagement in international and communal activities. She gained popularity when she promoted herself as the imam (leader) in Friday prayer of mixed gender in New York in 2005 (Hammer). The Friday prayer was attended by hundreds of followers, male and female. But her initiative was rejected by many Muslim scholars because it was regarded as not in line with Islamic teaching. In traditional Islam, a woman cannot be a prayer leader (imam) if there are male followers (jamaah) (Calderini; Stratton).

Wadud is forefront in promoting the equality of Muslim women through the reinterpretation of the sacred text, Qur'an and hadith. In her view, the Islamic jurisprudences that is implemented in Muslim society is commonly the interpretation by males, given the dearth of female Muslim scholars (Wadud Qur'an and Woman Rereading the Sacred Text from a Women's Perspective ). Furthermore, many traditional Muslims interpret the divine text literally without considering the social, economic and political background and current context. As a result, the implementation of Islamic moral values does not accord with modernity. An instance of this can be seen in the depiction that deals with Eve (Hawa), Maryam (mother of Isa/Jesus), and Bilqis (The Queen of Sheba). The depiction for these female characters put women as dependant and have no agency. Wadud considers that those characters contradict with true Islam in the era of the prophet
(Wadud Inside Gender Jihad Women's Reform in Islam).

The position of women in Javanese Muslim society is influenced by traditional Islamic teaching and other archaic values from Hinduism, Buddhism and animism (Creese; Hamdani 25).

Amina Wadud's view is based on the fact that the Qur'an does not mention God's preference of biological sex in creating a human being (Wadud Qur'an and Woman Rereading the Sacred Text from a Women's Perspective 29). Furthermore, in the creation of a human being, there is no gender stereotype (p. $15,29)$. Men and women have equal potential. Wadud refers to the Qur'an surah Al-Baqarah verse 30, which states that God will create human beings as the kholifah (leaders) in the world. Her interpretation of this verse is that the verse does not refer to specific biological sex.

And (mention, O Muhammad), when your Lord said to the angels, "Indeed, I will make upon the earth a successive authority". (Al Baqarah: 30)

Allah also states that men and women have the same chance to do good deeds. In the Qur'an surah An-Nahl verse 97 Allah said:

Whoever does righteousness, whether male or female, while he is a believer- We will surely cause him to live a good life, and We will surely give them their reward (in the Hereafter) according to the best of what they used to do. (An-Nahl: 97).

Amina Wadud maintains that the implementation of Islamic moral values in Muslim communities is greatly influenced by male ideology. She asserts that previous Muslim clerics used only the male perspective in interpreting the Holy Qur'an. Their depiction of women based on the Qur'anic construction is regarded by Wadud as discriminatory against women. The most fundamental is in interpreting phrases such as 'men are the leaders of women' (Qur'an 4:34). The interpretation of the Qur'an verse 34 can be interpreted that 'men are the maintainer of the women' in some life aspects. This verse is not merely about leadership of males over female but is about a privilege that men have over women maybe because of physical strength that make them responsible as maintainer for women. This misinterpretation has led to the subordination 
of women; as a result, women's social and political position in many Muslim societies is very low and governed by male authority (Wadud "Engaging Tawhid in Islam and Feminism").

\section{POLYGAMY IN INDONESIA}

In Indonesia, polygamy cannot be separated from the pesantren, the institution commonly regarded as a place that educates women to be pious Muslims, and where polygamy is accepted as normative teaching (Smith). However, it is important to acknowledge that there are two main types of pesantren, reflecting the diversity of Islamic ideologies. The first are the traditional pesantren, which use the kitab kuning ${ }^{l}$ as their reference. The second are the modern pesantren, which refer to the Qur'an and sunna in the teaching process. The modern pesantren commonly do not accept polygamy.

In Indonesia, the role of the pesantren in transferring patriarchal ideology is very significant (Nurish). There is a great number of pesantren in Indonesia, most of which, both traditional and modern, are led by a male Muslim scholar called a kyai. The position of a kyai is pivotal in the Indonesian Muslim social dynamic especially in Javanese society. Kyai are not only a spiritual support but some of them have political and social power too. As a result, the power of the kyai also influences government's decisionmaking. This can be seen in some districts that apply Islamic moral values that are regarded as syaria law (Afrianty).

$* * * * *$

The meaning of polygamy is having more than one spouse. The word polygamy comes from the Greek apolus meaning many and gamos meaning marriage. However, polygamy refers to men while the term that refers to women who have more than one husband is polyandry (Maryono). Some critics point out that there are three categories of polygamy: polygyny refers to a man who has married more than one wife, polyandry refers to a woman who has married more than one man, and a marriage group is a combination of polygyny and polyandry. However, polygamy is the most popular term in referring to a man who is married to multiple wives at the same time (Mustaqim).

The core concept of marriage in Islam is monogamy. The Indonesian feminist Sinta Nuriah (wife of former president Abdurrahman Wahid) points out that An-Nisa verse 129 is intended to emphasise that the marriage concept in Islam is monogamy (White 341). The right to marry one, two to four wives, is only allowed in certain circumstances (for example, to protect orphans or to protect a woman in a difficult condition) and was applicable only in the era of the prophet. Polygamy was allowed in Islam because Islam was revealed in the era of jahiliah (ignorance), where Arabian society was in a worse condition than it is now. At that time a male could marry unlimited wives, whereas Islam limits polygamy to four wives (Maryono).

In Indonesia, polygamy is not practiced only by Muslims: other creeds and religions also practice polygamy, including Balinese Hindus and Chinese Indonesians, and in traditional Javanese custom aristocrats are entitled to many wives called selir (secondary wives) (Nurmila 30). In this kind of polygamy, conducted according to local culture, there is no limitation on the number of wives. For instance, a Javanese aristocrat can have more than ten wives or even hundreds of concubines (selir). However, because the practice of polygamy is not promoted in other religious communities, most polygamy issues in Indonesia will be related to Islam or the Muslim community.

Many modern Muslims reject polygamy, although some believe that it is allowed by God. The conditions for polygamy are very strict and very hard to fulfill. Despite this, and despite the injustice that may be inflicted on women and children, there are many Indonesians who practise polygamy. Nurmila's 2007 research revealed that polygamy is not only practised by the well-off but also by poor people. However, most are from the middle and upper economic social class (Nurmila).

Some Muslims who support polygamy use the Qur'an surah An-Nisa verse 3 to justify this:

And if you fear that you will not deal justly with the orphan girls, then marry those that please you of (other) women, two or three or four. ... (Qura'an An Nisa verse: 3).

This verse is interpreted by some Muslims to mean, that polygamy is allowed in some conditions, such as when a woman is infertile, unable to serve the sexual desire of her husband or for some other reason such as a busy businessman who needs to travel regularly while the first wife needs to take care of their children.

Wadud, however, disputes that this verse deals with marriage and maintains rather that it is 
about how to manage and take care of orphans. It is thus a verse that is no longer applicable in the modern day (Nurmila; Wadud "Towards a Qur'anic Hermeneutics of Social Justice: Race, Class and Gender"). Furthermore, if attention is paid to the surah (An Nisa: 3 ), at the end of the verse Allah also states that it will be difficult for a human being to be just to more than one wife (An-Nisa verse 129). Therefore, the verse teaches that it will be better for a Muslim man to take only one wife (Rohman; Wartini).

$$
* * * * *
$$

In Indonesia, the controversial issue of polygamy was triggered after the reformation era when democratisation occurred. Both the pro and contra side have aired their ideas, meaning both supporters and challengers of polygamy have received public attention. It became a burning issue when the entrepreneur Puspo Wardoyo promoted polygamy through his business. He itemised the menu in his restaurant using terms such as polygamy juice (made out of avocado, mango, soursop and papaya) with the view that the practice of polygamy should be more visible and acceptable in Muslim society (Wichelen). In 2003 he also promoted a polygamy award, given to a man who was successful in conducting polygamy (van Wichelen; Nurmila). The second high-profile incident occurred when the populist Muslim preacher, Abdullah Gymnastiar (popularly known as AA Gym) took a second wife, giving rise to public debates about polygamy.

In responding to these issues, the government took action to prevent the practice of polygamy by revising the law of marriage. Susilo Bambang Yudhoyono (SBY, the sixth president of Indonesia) urged the Minister for Women's Empowerment, Meutia Farida Hatta Swasono, to revise the marriage law number 45, 1990 and number 10/1983, which concern marriage and divorce for civil servants (Ronaldo).

The government imposed strict rules of marriage upon Muslims by raising 5 government regulations aimed at preventing state civil servants from practising polygamy. As Wartini explains, the principle of Indonesian marriage law is monogamy, however, a Muslim man can marry more than one wife in a specific circumstance with the permission of the local court (Wartini).

Marriage law no 1 article 2 states that the court can permit a husband to have more than one wife, and article 4 states that a man can have more than wife if:
- His first wife cannot do her obligation (especially in fulfilling sexual desire)

- His first wife has a physical handicap or illness that cannot be cured.

- His first wife cannot give birth.

Article 5 states that in order to engage in polygamy a Muslim man needs to have:

- permission from his first wife.

- guarantee that he can provide for all of his wives and children's needs.

- guarantee that he can be just to all of his wives and children.

This Indonesian law of marriage is the result of the interpretation of the Qur'an based on An-Nisa verse 3 where a man can marry four women. In considering the negative effect of practising polygamy, the government management of it is very strict. This can be seen when SBY's administration punished Syaik Puji (a leader of pesantren Miftakhul Jannah and a successful businessman in Semarang, Central Java) when he took Maria Ulfa as his second wife. Syaik Puji was sent to jail not only because he married Maria Ulfa as his second wife, but also because Maria was under 16 years of age.

\section{POLYGAMY IN INDONESIAN LITERATURE}

Polygamy is perhaps the most significant issue relating to Muslim women to be raised in Indonesian literature after the reformation era. The first writer to raise this issue, based on Islamic teaching, was Habiburrahman EL Shirazy, in his novel Ayat-Ayat Cinta (AAC) in 2001. Other depictions of polygamy occur in Namaku Naura (NN) by Alfina Dewi and Perempuan Berkalung Sorban (PBS) by Abidah EL Khalieqy. Each writer presents different views because they bring their own worldview to their work. El Shirazy and Alfina Dewi promote Islamic moral values in their writing while El Khalieqy challenges polygamy.

\section{Polygamy in Namaku Naura by Alfina Dewi}

The complete title of this novel is Namaku Naura: Semakin Jauh Cinta Melangkah, Semakin Pedih Luka Perpisahannya (My Name is Naura: The More Love Grows, the More Bitter the Farewell). Published by the Yogyakarta Publishing House in 2012, its 465 pages include a sketchy biography of the writer. This is her only novel.

Alfina Dewi is a Muslim woman with two children from Jombang, East Java, where she sometimes teaches in a pesantren. Like the protagonist 
of her novel, she is married to the son of a Kyai. Her life is dedicated to her children and her husband.

Dewi is a graduate in Economics from Widya Gama University in Malang, East Java. She also learns Islam informally from some young Islamic teachers, most of them sons of Kyai. This type of education is very common in East Java. It is known as informal Islamic teaching because the students do not live in the pesantren; they just come to a pesantren to study religion. One of Dewi's favourite teachers was Gus Orbar Sadewo Ahmad, son of the very influential Kyai Hamim Jadjuli.

\section{Plot of the Novel}

The novel tells the story of 23 year old Naura Dewi, who is studying about Islam. One day she and her friend Nana visit a mosque close to her house to listen to an Islamic preacher, a young man named Muhammad Fariza.

After the initial meeting in the mosque, Naura and Nana become frequent visitors to the pesantren of Kyai Ahmad (Fariz's father). Like many other people in her area, although she is not living in the pesantren she often joins in religious classes there. Her parents also learn Islam by coming to the pesantren or local mosque.

Naura likes coming to the pesantren because Fariz, her teacher, is very friendly and welcoming to her. Fariz pays much attention to her and sometimes he teases her. Although Naura knows that Fariz likes her, she keeps her distance from him because she knows that Fariz is a married man.

Although she is reluctant to respond to Fariz's advances, she likes him secretly. She tells her friend Annisa that she admires his politeness and his gentleness. According to her, he is not only a clever young man but also handsome with an authoritative bearing.

They begin to conduct a relationship in secret and sometimes Fariz comes to her parents' house. Eventually, Fariz tells Naura that he and his wife do not live in the same house because they are having marital problems.

Fariz's explanation is that his wife is stubborn and does not obey to him. As a result, they often quarrel. They have different life goals, which leads to further disagreement. In this view, the stubbornness of his wife has left him unable to do the things he needs to do in order to be a success in life. She does not support his idealism as a Muslim scholar and as a member of the Regional Representative Council
(DPRD, Dewan Perwakilan Rakyat Daerah).

Naura is in a predicament because she does not want to damage Fariz's young family. As a young woman, she knows how hurtful it will be to Fariz's children if he divorces his first wife because of her. On the other hand, Naura loves Fariz very much and she cannot face leaving him.

Fariz, too, does not want to lose Naura. Therefore, he asks her to marry him, to be his second wife.

Although Naura is prepared to be a second wife, she is not sure whether the decision will be accepted by Fariz's first wife. Therefore, she asks Fariz to focus on his family; after he has solved his family problem he can take the further decision to marry or forget her.

It is not the case that no other man wants to be Naura's husband. Robby, Fariz's nephew is also interested in her. However, she cannot accept Robby because she loves Fariz too much.

Although Naura does not accept Robby's proposal, they still have a good relationship. Robby knows that Naura is his uncle's beloved and he knows how to behave in order not to corrode their friendship.

Fariz and Naura finally get married without permission from Fariz's first wife. This decision is taken by Fariz because he and his wife have lived apart for so long. Fariz and Naura marry secretly in a marriage based on Islamic law known as nikah siri. Nikah siri is performed by a Muslim based on Islamic jurisprudence: the marriage is not reported and recorded in government. They conduct the wedding ceremony without the attendance of Fariz's parents or his first wife.

They hold the marriage ceremony in the place where Fariz will build a pesantren for Naura (as the place where Naura will dedicate her life to Fariz and her children), only inviting a few people who they know well, such as Anisa and Nana, while Fariz only invites Robby and his brother as his guide.

After some time, Fariz's first wife becomes aware of their marriage. This makes her angry. She accuses Naura of stealing her husband from her. When Fariz's first wife find out about their marriage, Naura is already pregnant.

Fariz sometimes visit his first wife because he wants to see his children; he also wants to make a better relationship with his first wife. However, his first wife asks him to divorce Naura or she will take him to court. This would cause significant problems for Fariz as a member of the legislative council; it 
could endanger his position and the good name of his family.

Faced with an impossible situation, he divorces Naura. The decision actually comes not from Fariz but from Naura, who does not want to cause problems for Fariz and his family.

After divorcing Fariz, Naura's high school friend Donny proposes marriage to her. Naura rejects Donny's marriage proposal because she is still waiting for Fariz.

Despite the divorce, the quarrel between Fariz and his first wife is not resolved. Fariz also discovers that his first wife has been having an affair with another man. This leads to his first wife asking for divorce. He takes all his children to the pesantren where Naura lives.

Although Fariz has divorced Naura, he still hopes to get back with her and he still keeps in contact with her. After his divorce, he focuses on his job as a member of the DPRD in his district, while the pesantren is managed and organised by Naura.

About three years after divorcing his first wife, Fariz finally asks permission from his parents to remarry Naura. His parents and family approve. For this second marriage, they hold a bigger celebration inviting about five hundred people. This marriage makes their children happier because they can live as a big family in the pesantren they have built.

At the end of the story, Naura is living happily with Fariz and Fariz's children Salsa and Faiz. Fariz's first wife lives alone and rarely sees Salsa and Faiz because they do not want to see her. They are angry with her because they think that she has ignored them when they needed her attention. This causes her guilt; furthermore, she has also lost her lover.

\section{A Pious Woman}

$\mathrm{NN}$ can be categorised as Islamic literature or sastra Islami, that is, literature that uses Islamic teaching as its foundation (Osman). Indications that this novel presents and affirms Islamic moral values include how the main characters are presented, such as Naura's daily activities and how she faces life's problems. As a pious Muslim woman, Naura is heavily involved in spiritual activities. At the beginning of the novel Naura describes her morning routine:

This morning when I woke up I was still on the prayer mat, having fallen asleep after the dawn prayer. I felt stiff all over from lying on the floor. I took off my prayer robe immediately, and when I looked at the clock on the table it was seven o'clock. ... You gave me the pleasure of the tahajud last night, followed by the calm of the dawn prayer (p. 7) ${ }^{2}$.

The reference to the tahajud (night prayer) indicates that Naura is not only doing the obligation of five daily prayers but also the sunna prayer ${ }^{3}$. In Islam, people who do sunna activities indicate that they have a higher level of iman (faith).

The author's aim in this novel appears to be to depict a pious Muslim woman devoutly following and accepting religious instruction, including accepting the traditional teaching about polygamy. Naura hopes that God will give her what is best for her although she must be a second wife: an affirmation of patriarchal ideology that contradicts with the spirit of equality between men and women. This is also against the values of the Qur'an surah An Nisa verse 129. “And you will never be able to be equal (in feeling) between wives, even if you should strive (to do so).... (Qur'an Surah An-Nisa verse 129). This surah is interpreted by many modern Muslim scholars to mean that the best marriage in Islam is monogamy. Polygamy is only sunna (allowable in certain circumstance). For feminist Muslims polygamy is rejected as inappropriate for modern Muslims.

The values that are presented in this novel are not based only on the Qur'an and the hadith but also on interpretations of the holy book known as kitab kuning. A Kitab Kuning is an interpretation of the Qur'an and hadith written by medieval Muslim scholars (Nurmila). As such, the Islamic moral values reflected in this novel contradict what are regarded as modern Islamic values. Furthermore, this novel also runs counter to notions of the modern Muslim woman.

The novel applies and affirms conservative Islamic teaching: the characters unquestioningly accept polygamy. The main characters follow their feelings without heed to Islamic jurisprudence or the Indonesian marriage law. The main character, Fariz, marries Naura as his second wife because his first wife does not obey him. This too is against the Indonesian marriage law and true Islamic teaching.

$$
* * * * *
$$

The story is written in the first person, with Naura telling her own story of her love of Fariz. The author thus presents perceptions of polygamy from a woman's viewpoint. This novel can be regarded as the representation of a conservative Muslim female's opinion of polygamy. Polygamy is accepted 
uncritically without regard to modern interpretations of the Qur'an and the hadith (sunna) that teach about the practice of polygamy in Islam.

As this novel is supporting the implementation of polygamy in a conservative Muslim society, it is out of step with modern interpretations of the Qur'an and with the Indonesian marriage law.

In modern Javanese society, some Muslims take another woman to be their wife simply in the belief that polygamy is part of the implementation of the sunna of the prophet. They do not consider that the prophet lived in a different era than the modern one, in which polygamy is no longer appropriate. Ironically, some conservatives are supported by their first wife because of the belief that polygamy is a part of the implementation of iman ${ }^{4}$. Some conservative women do not realise that this kind of teaching is the product of a patriarchal ideology that dominates in the interpretation of the holy book. As Wadud points out, this is a misleading interpretation of the holy book, whereby only males were the authorised to interpret the Qur'an (Wadud "Towards a Qur'anic Hermeneutics of Social Justice: Race, Class and Gender").

$$
* * * * *
$$

Dewi's work appears to be an attempt to reflect what is happening in traditional Javanese Muslim society: that some Javanese Muslims still engage in polygamy merely based on love, not because of physical or mental illness or other circumstances. Some do not get permission from their first wife. This means that a husband who secretly marries a second wife has cheated on his first wife. Ironically, they legitimate their decision to engage in polygamy using Islamic moral values. They do not consider the circumstances that made the prophet Muhammad (PBUH) endorse polygamy for sociological and theological reasons.

As revealed by Wichelen (2009) there are still many traditional Muslim who engage in polygamy. His research shows that there are some reasons why a woman may allow her husband to take another wife or why a woman wants to be a second wife. The first reason is that she does not want her husband cheating on her. Some women also mention that polygamy can be a solution for a Muslim career woman. When a career woman and her husband are busy with their business, her co-wife can take care of their children, or if one of the wives is sick the other wives can help her to manage the household. The last reason is economic. In Javanese society there are many women who are financially insecure; by becoming a second wife, her husband can protect a woman from economic difficulties (Wichelen 178).

Economic factors have a key influence on a woman's independence. In a traditional Javanese Muslim marriage, a husband usually should be of a higher social, economic and political position than his wife because the husband is the leader in the family. The assumption is that a wife from a lower social and economic position will be more respectful to her husband and more loyal. This is reflected in the novel: Fariz has a higher social, economic and political position than Naura.

The inferior position of Naura to Fariz is also reflected in her parents' social and economic status. Naura's father is a farmer and her mother is a housewife. Her parents cannot send her and her elder brother to university. Both Naura and Rachmat only graduated from senior high school. After finishing senior high school Naura takes a computer course, while her elder brother has to work in Japan as a TKI (Indonesian migrant worker).

When Naura marries Fariz the difference in their social classes makes it easy for Fariz to take control.

The novel appears to support patriarchal ideology, which is presented through the depiction and affirmation of traditional Islamic moral values. The female characters have total obedience to men (a wife to her husband and a daughter to her father). If a wife cannot follow her husband willingly she is regarded as disobedient or not sholehah ${ }^{5}$. In this case, Fariz's first wife is placed as the antagonist of the novel.

What is presented in the novel, such as the way the characters accept polygamy and their way of daily worship, in fact contradicts what is Islam in the era of the prophet. As mentioned above, in the era of Prophet Muhammad, there were many women who were active in the public sphere.

Traditional Javanese Muslims usually have total loyalty to their teacher. Obedience is regarded as one of the good akhlaq (attitudes) that should be followed by traditional Muslim. Therefore, they have no right to argue if they find something goes against their rational thought. This can be seen in Naura's attitude when she and Nana meet Fariz after he has given a speech at a meeting of the Islamic class:

"Let's go meet him!"

Oh..., how could I... I would have to sungkem, to be close to him, to kiss his hand. Could I do 
that..., my heart might explode! (p. 35)

Sungkem is the act of kissing someone's hand. It is usually done to an older man or woman or teacher (of the same sex) to show respect. Although males and females apart from mahram ${ }^{7}$ must not make skin contact, sungkem is commonly done in some traditional pesantren.

As a Javanese Muslim male, Fariz has more freedom than Naura. Females are controlled and restricted by rules made by their fathers and their society. For instance, the female is limited by her body, which is regarded as weak and full of sin. As a result, everything done by females needs to be careful and sometimes needs consideration by their parents.

As this novel champions patriarchal ideology, it also conveys the notion that a pious woman should be calm, shy and respectful to her parents and older people. Naura is very respectful to her parents, especially to her father and to her husband.

Fariz's higher social position make him more confident. He does not feel guilty in establishing a relationship with Naura although he is a married man. Ironically, Naura's parents accept and respect Fariz; they are not angry at knowing that their daughter has a secret relationship with him. They feel proud and happy that their daughter has a close relationship with the son of kyai and as such, they are surprised that Fariz would want to visit their house. What is presented by the writer here is the status quo of the accepted dominance of the male in Javanese Muslim society.

Besides being the son of a kyai, the second privilege afforded to Fariz is a good education. People will regard a man with higher education as likely to bring success to his family. Furthermore, in Javanese Muslim society higher education in religious studies is regarded as more prestigious than general knowledge. That is why Fariz's combination of being the son of a kyai and having had a higher education is a valuable attribute for him.

To Naura, Fariz is the perfect man, as can be seen in her reverie:

I gazed at him. I must admit that I rated his face alone at 8.5. And his knowledge was something else (p. 11) .

Javanese Muslim traditions are inevitably influenced by the traditional Islamic teaching that the decision to divorce is the male's prerogative. As the woman is regarded as an emotional human being, she cannot take the decision to divorce in Islam. As the leader of the family, a husband should be older than his wife because it is assumed that an older person has more stable emotions and is wiser than a young one. According to Wadud the Islamic teaching about male's authority in divorce is not relevant anymore, because males and females should have the same right in proposing divorce.

A good social standing provides Fariz with immunity from negative judgment by society. A kyai is regarded as a "holy" position in Javanese society, therefore, most people will believe in him whatever he says. This is very different from the situation of common people who will be criticised if they cannot manage or organize their family well. Furthermore, a man with a broken marriage will be regarded in a negative light within his community, making it difficult for him to find another woman to be his spouse. Fariz is above such stigmatisation.

$$
* * * * *
$$

Fariz's explanation to Naura about his first wife is important in understanding how the Javanese (Muslim) man wants to his wife to be. Her possessiveness becomes a problem for him; he wants his freedom. He does not want his wife to control him too much. This is an indication that the dynamic between Fariz and his wife is not equal. Fariz treats Naura as his servant while he asks his wife to treat him as a king. This model is influenced by traditional Javanese values whereby a husband should be respected and obeyed by his wife.

In traditional Muslim society, women always become the victim if family conflict happens. The woman inevitably becomes the victim because she will be regarded as not obedient to her husband or she is regarded as not professional in managing the household. Furthermore, if a violence occurs in a traditional Muslim family, the husband is beyond reproach because he has the rights to teach or remind his wife. This occurs because of the misinterpretation of the Qur'an Surah An-Nisa verse 34, whereby men are regarded as the leader of the women. As stated in Nilan at.al. (2015), marriage abuse is difficult to judge because a husband usually uses his position as the leader of the family so that the abuse is associated with his right to teach or remind his wife (Nilan et al.).

The privilege of Fariz as a Muslim man also can be seen in his position on the marriage process. In the marriage process, a Muslim man does not need a guide (wali). Although he needs to ask for permission 
or advice from his parents, he can marry a woman without any guidance from them. This is different from a Muslim female, who needs advice, permission and guidance from her parents. In the novel, Naura's parents, especially her father, need to come to the wedding while Fariz's parents do not come to the ceremony. Fariz simply asks his older brother to be a witness of his wedding.

In a traditional Muslim society, parents determine a spouse for their daughters. Sometimes, a daughter has no power to reject a marriage proposal from a married man because of this traditional value. In the case of Naura and Fariz, Naura's parents, representating traditional Muslim, accept Fariz as their daughter's spouse. Although at first, they advise her not to marry Fariz because they know that he is already married, eventually Naura's parents do not forbid her from marrying Fariz. This is of course because of Fariz's social standing.

After discussing the matter, Naura's father says:

"It's up to you, child... we have advised you, you're the one who must take responsibility. If you decide to do that, okay, it's up to you ..., we will just pray for you. We hope he is the best for you." (p. 130)

After they marry, Naura is depicted as a second wife who always supports her husband. She never complains. She has to live away from the public eye in a small pesantren to which few people have access. Furthermore, because Fariz is busy with his job Naura has to accept the consequence that she has very limited time with her husband. This can be seen when Naura explains to Robby, "Sometimes he's only at home from dawn until mid-morning, and even then only on the weekends." (p. 140) ${ }^{10}$

However, Naura cannot complain because right from the beginning, Fariz has taught her that to be a pious woman she need to sacrifice her husband to do social and political activity in the name of his struggle for his religion. If Fariz says that whatever he does is for religion, Naura cannot complain. She has to support her husband. As she says to Fariz:

“...don't worry, I will accept whatever you give me. I stand beside you, not to be a burden on you, ... let me lighten your burdens." (p. $137-138)^{11}$

Naura assumes that submission to her God is through her obedience to her husband. As a part of this obedience, she dedicates her life to her family. This kind of obedience is against the true nature of modern Islam, whereby every human being will be rewarded based on their own effort (Qur'an Surah Al-Fatir verse 18-23). Men and women have their own way to dedicate their life to their God. Therefore, Naura's obedience to her husband and sacrificing of everything to get the blessing of her God is misguided. Furthermore, the Qur'an also states that: 'And no bearer of burdens will bear the burden of another. And if a heavily laden soul calls (another) to (carry some of) its load, nothing of it will be carried, ... (Qur'an Surah Fatir verse 18).

Her total obedience to her husband renders Naura powerless and dependant. She also becomes a fatalist, in that she believes that whatever happens in her life is because of her God. This means she has no choice but to accept whatever happens. She does not seek her own solutions when she faces family problems; she waits and depends on Fariz and other men including Robby and Donny who always work hard to sustain the pesantren.

Female independence is not a feature of this novel. Although Naura is depicted as the owner of the pesantren, she has it because of her husband. Furthermore, she herself cannot manage the pesantren, rather she depends on Fariz, Robby, Rachmat and Donny.

$* * * * *$

The novel paints Fariz's first wife in a negative light because of her affairs with another man. Traditional Javanese Muslims consider it unusual for a married Muslim woman to have an affair; it is regarded as a grave sin. Yet Fariz's action (having a relationship with Naura) is regarded as common. The double standard is clear, but the novel can be read as an endorsement of traditional Islamic teaching where a man can marry without permission from his family or his first wife.

The authority or purported superiority of a husband can be seen in Fariz's decision to divorce his first wife after knowing that she has had an affair with another man. It is not, however, open to his first wife to divorce him when she knows that Fariz has taken a second wife without her permission. This is because the authority to divorce is on the male: a female Muslim does not have the authority to divorce her husband.

$* * * * *$

The authors' background is important in understanding 
the worldviews depicted in these novels. Although $\mathrm{NN}$ is written by a female writer, patriarchal ideology is very strong in this novel. As stated above, Dewi studied Islam in a traditional Islamic institution, meaning that the conservative viewpoint has had a formative influence on her. The traditional pesantren does not usually consider the contextualisation of the Qur'an and hadith in the modern era. Therefore, what is stated in the Qur'an and hadith is applied without considering prevailing social and political conditions.

The traditional interpretation of Islamic jurisprudence is evident in the position of the Muslim women in the novel: subordinate to men and whose role is only as a supplement to men. Nor can women contribute to the broader social and political dynamics of their environment. A woman's role is limited to taking care of the family and her husband, as can be seen in Naura preferring to dedicate her life to her husband and her children. She is financially dependent on Fariz's earnings and the business given by Fariz as part of the divorce settlement. This goes against Islamic teaching whereby every human being will depend on their own good deeds (Qur'an surah Saba verse 25). Moreover, every human is judged based on their own faith (to God) individually not based on their obedience to their family or husband.

\section{Ayat-Ayat Cinta}

Ayat-Ayat Cinta (The Verse of Love, henceforth AAC) is a novel written by Habiburrahman El Shirazy. This is the most popular among the Indonesian novels that apply Islamic moral values, not only because it raises the controversial issue of polygamy, but also it presents new perspectives on modern Islam in the Indonesian context. This novel gained its popularity after it was adapted into a film in 2004. AAC is not only popular in Indonesia but also in Malaysia, Brunei Darussalam, and Singapore (Heryanto; Sakai).

El Shirazy sets out to present the issue of polygamy based on his interpretation of the Qur'an or Sunna. This can be seen in the references he uses in the novel. El Shirazy has stated that writing is one way in which he promotes Islamic moral values ${ }^{12}$. However, what he depicts in AAC suggests a misinterpretation of the Qur'an especially surah An-Nisa verse 3. He interprets this surah as simply dealing with circumstances in which polygamy is permissible, but as Wadud points out, the true intention of this verse is actually about protecting orphans (Wadud Qur'an and Woman Rereading the Sacred Text from a Women's Perspective 83). Therefore, although polygamy, as undertaken by the main character, is in accord with Indonesian marriage law, it is still out of step with modern interpretations of Islam.

\section{Plot of the Novel}

The novel begins with the achievements of the main character Fahri, a Masters student in religious studies at Al Azhar University in Cairo. He is diligent not only in studying but also in conducting his own business, as tempe (Indonesian traditional food) seller. Although he is a busy student, he is also active in extra-curricular activities in the Indonesian community as well as studying Qur'an interpretation with Syaikh Utsman Abdul Fattah at Abu Bakar Ash Shidiq mosque.

Fahri is lucky being able to study with Syaikh Utsman because Syeikh Utsman only takes on ten students each year. And for this year, Fahri is the only student from Asia.

There are four fellow students living in the flat with him. Fahri is the oldest and the most senior, so he is appointed as the leader in the house. The other are Saif, Rudi, Hamdi, and Mishbah.

They have a good neighbour, Mr. Boutros, who is Christian Coptic. He has a beautiful daughter called Maria or sometimes called Mariam. She is very friendly to Fahri and eventually falls in love with him, but Fahri does not reciprocate her attention.

Fahri finds Maria to be an unusual girl. Although she is a Christian, she likes to learn the Qur'an. She also can memorise some surah especially Surah Mariam, which deals with the story of Maryam, the mother of Isa (Jesus). As a student at Cairo University, it is understandable that she needs to learn about Islam (p. 23, 24).

Fahri is also close to Syaik Ahmad Taqiyyuddin Abdul Majdi, an imam proficient in reading Al-Qur'an. $\mathrm{He}$ is a hafiz (someone who are good in memorising the Qur'an) and also a scholar of Islamic history.

On the way to Abu Bakar Ash Shidiq Mosque, Fahri meets a woman wearing a turban. Her name is Aisha. The bus is full of passengers, so Fahri gives her his seat, an action intended to demonstrate his respect for women in accordance with Islamic moral values. The communication between Aisha and Fahri intensifies because she helps Alicia (an American journalist) interview Fahri about Islam.

At a party to celebrate Fahri's success as a Master candidate, a young woman called Naura appears crying and asking for help because her stepfather, Mr. Bahadur has hit her. Wanting to help Naura, Fahri asks Maria to bring Naura to her 
apartment. Maria and Mr. Boutros tell Fahri that they are afraid that Naura staying in their house will create a misunderstanding between Mr. Boutros's family and Mr. Bahadur. The solution is to send Naura to a house where Indonesian women students stay. Fahri contacts Nurul, the leader of Wihdah, a centre of Indonesian Students in Egypt. Fahri asks Nurul to help Naura because Islam teaches that a Muslim man cannot directly help a woman without companions (in traditional Muslim, a woman and a man cannot go out together without a companion or muhrim).

Fahri always applies Islamic understanding in his life, including when he decides to marry Aisha, as proposed by Syeikh Utsman. The decision to accept Syeikh Utsman's proposal is not because he cannot reject the proposal from his guru, but because in the Islamic tradition a Muslim man can ask his guru for help when he is ready to get married. He just needs to ensure that the woman that is proposed by Syeikh Utsman is suitable with the criteria he wants. Therefore, although Fahri does not know the woman who is proposed by Syeik Utsman, he trusts him.

It is a surprise for Fahri then when he discovers that the woman proposed by Syeik Utsman is Aisha whom he has met on the bus.

Not long after their marriage, Fahri and Aisha face some obstacles. Their marriage is a cause for disappointment among some women who love Fahri: Nurul, Maria and Naura.

The most difficult challenge is when Fahri has to take a decision to take Maria as his second wife, because she is heart broken. Naura resents Fahri because he does not choose her as his wife, and this resentment leads to accuse hi of rape.

Although in a difficult situation, Aisha allows Fahri to marry Maria because she wants to help Maria to cure her sickness. Maria is also the only one who knows the problem Fahri faced when he helped Naura. Because of Maria he can be free from Naura's allegation that he raped her.

The story ends with the death of Maria (a few months after they get married) because of her illness.

\section{Polygamy}

In AAC polygamy is not the main issue. The story tells more about the characteristics of a pious Muslim as represented in the main character, Fahri. Polygamy is not raised until almost the end of the story. However, the position of the author is clear: he supports polygamy. His message is that polygamy is allowable as long as it does not corrode Islamic jurisprudence and the Indonesian marriage law. This can be seen from the scene when El Shirazy depicts Fahri marries Maria (as his second wife) using the rationale that he has to help Maria cure her disease (heartbreak). Fahri does, however, gets permission from his first wife, Aisha.

Although El Shirazy has tried to follow the Indonesian marriage law that is based on Islamic jurisprudence, this worldview discriminates against women's. Permission to undertake polygamy reduces women to objects with no agency. If a man can marry another woman because of his first wife's inability to fulfill her responsibility as a wife, the question needs to be asked about a wife whose husband cannot fulfil his responsibility as a husband. Can she also take another man as her second husband? As Wadud reminds us, according to Islam males and females have the same position before God (Wadud Inside Gender Jihad Women's Reform in Islam).

Although the Qur'an clearly states that the best marriage concept is monogamy (An-Nisa verse 129) many Javanese Muslim women do not realise this, and some still uncritically accept polygamy. This is seen in the novel when Fahri receives a marriage proposal from Nurul.

"Please forgive me for writing this letter, Fahri. But if I didn't, the regret would intensify as time goes by. For a woman, if she loves a man, the man is everything for her. It is difficult to forget one's first love, especially a love that has become deeply entrenched. And that's how I feel about you. If there is any chance I ask you to open your heart for me so that I can feel the sweetness of life with you. I do not want to violate Islamic law. I want to do this in accordance with Islamic law." 13

Nurul is clearly interested in being Fahri's second wife; her love for him emboldens her to say so directly to him, although this will incur Aisha's wrath. The author depicts Nurul's family background, which is important in understanding her action. She was raised in a traditional pesantren in East Java, where polygamy among the kyai is very common (Rohman).

El Shirazy strengthens his affirmation of polygamy by presenting women who are sholeh acccording to the male perspective. Sholehah is usually associated with a Muslim woman who is passive, meek, modest, obedient, self-sacrificing and nurturing (Wieringa). These characteristics are represented in Aisha, Nurul, and Maria. Nurul knows 
that Aisha is a sholehah woman, and she assumes that Aisha will agree with her because Islam allows a husband to have more than one wife.

As in NN, piousness for a woman is associated with obedience, calmness and shyness. Furthermore, in this novel, piousness is associated with the obedience of women to accept everything from the religion. Nevertheless, the teaching that they are expected to accept is that which benefits men. This is unacceptable in modern Muslim society. As Wadud (1999) asserts, in relation to worship or good deeds no one can depend on another except directly on God. If a Muslim woman is dependant on her husband in worship, it is known as syirk (deifying her husband as a god) (Wadud Inside Gender Jihad Women's Reform in Islam 40).

\section{CONCLUSION}

Although NN and AAC present a different view of polygamy, these novels can both be read as an affirmation of the fact that polygamy is acceptable in traditional Islam. NN depicts orthodox Islamic moral values where there is an uncritical acceptance of polygamy. AAC conveys the message that polygamy is still applicable for Muslims in contemporary Indonesia, as long as the Indonesian marriage law is followed.

Based on that, this is an indication that these literary works reflect what is happening in the Indonesian society. Traditional Islamic moral values are still followed by the society. There are many conservative Muslim that still hold the traditional values.

Therefore, based on Wadud's worldview, polygamy as presented in both $\mathrm{NN}$ and AAC contradicts human rights because by engaging in polygamy a man has placed himself as higher than a woman. The position of women in these novels is subordinate to men. In addition, both novels also affirm that the relationship between women and God is mediated by men. As a result, the social and theological construction of these novels situates women's faith (keimanan) as being dependant on her husband or her parents. This is an unacceptable theological conception of women in Islam. In Islam, every human being is directly connected to God. A woman does not depend on a man in relation to her worship to $\operatorname{God}^{14}$.

Both novels, in fact, present views that are against true Islamic jurisprudence especially that stated in the Qur'an surah An-Nisa verse 129. This verse clearly asserts that a man will not be able to be just to more than one wife, therefore the ideal marriage concept in Islam is monogamy. In conclusion, what is depicted in these novels is not appropriate for a modern Muslim society that values equality and freedom.

\section{ACKNOWLEDGEMENT}

This paper is part of my $\mathrm{PhD}$ research Project with title "Images of Muslim Women in Contemporary Indonesian Literature". The research is supported by the Ministry of Research, Technology and Higher Education of the Republic of Indonesia and Tasmania University, Australia.

\section{ENDNOTES}

1) Kitab Kuning is Islamic teaching based on Qur'an and hadith that was written by medieval Muslim scholar (mostly male).

2) Pagi ini aku terbangun masih di atas sajadah, ternyata aku tertidur pulas habis subuhan tadi. Rasanya badanku sakit karena beralas lantai. Segera ku lepas mukena, dan ketika kulihat jam di atas meja sudah menunjukan angka tujuh. .. Engkau beri aku nikmat Tahajud semalam dan subuh yang sahdu (p. 7)

3) Sunna is an activity that not mandatory but suggested. In Islam a Muslim who routinely conduct sunna is regarded as a person with good faith (iman).

4) For instance, it can be seen in the case of Puspowardoyo (polygamous Muslim man who has four wives), Arifin Ilham (Muslims preacher with two wives) and Ja'far Umar (an influential Muslim scholar who also has four wives from Jogjakarta). The new one is Abdullah Gymnastiar, a famous Muslim preacher who take a widow with three children as his second wife.

5) This is common for traditional Muslim that a wife who disobedient to her husband is regarded as not good women. It is because a piousness of a wife is considered from her attitude, one of them is her obedience to her husband.

6) "Sungkem yuk!"

Aduuuh..., gimana niiih... sungkem berarti mendekat kepadanya, mencium tanganya. Apakah mampu aku..., bisa meledak jantungku! (p. 35)

7) Mahrem or muhram is an unmarriageable kin with whom sexual intercourse would be regarded as incestous and punishable taboo in Islam.

8) Kupelototi dia. Tapi, memang harus kuakui, dalam ukuran skalaku nilai wajahnya 8,5 . Belum nilai keilmuanya. (p. 11) 
9) "Terserah kamulah, Nduk.... bapak, ibu, sudah memeberimu nasehat, kamu yang menjalani. Kalau kau memutuskan begitu, ya terserah..., bapak ibu hanya berdoa saja. Semoga dia jadi yang terbaik untukmu." (p. 130).

10) "Gak sepertinya, jadwalnya padat hari ini. Kalau datang biasanya dini hari sampai pagi beliau di sini, itu pun hanya di akhir pekan." (p. 140)

11) “... jangan risaukan itu, aku akan terima seberapapun yang Mas beri untukku. Aku disamping mu bukan untuk menjadi tambahan bebanmu, Mas..., jadikan aku peringan segala bebanmu." (p. 137-138)

12) See https://www.youtube.com/ watch?v=F5OJfRggMFM

13) "Kak Fahri. Sungguh maaf aku sampai hati menulis surat ini. Namun jika tidak maka aku akan semakin menyesal dan menyesal. Bagi orang perempuan, jika ia telah mencintai seorang pria, maka pria itu adalah segalanya. Susah melupakan cinta pertama apalagi yang telah menyumsum dalam tulangnya.dan cinta ku padamu sperti itu adanya, telah mendarah daging dan menymsum dalam diriku. Jika masih ada kesempatan mohon buakanlah untuk ku untuk sedikit menghirup manisnya hidup berasamamu. Aku tidak ingin yang melanggar syariat. Aku ingin yang seiring dengan syariat."

14) See Wadud's speech in https://www.youtube.com/ watch? $\mathrm{v}=$ EqfybmUD4xw\&t $=10 \mathrm{~s}$

\section{REFERENCES}

Afrianty, D. (2011). Local women's movements in Aceh and the struggle for equality and justice: the Women's Network for Policy. RIMA: Review of Indonesian \& Malaysian Affairs, 45(1/2), 37 68. Retrieved from https://login.ezproxy.utas. edu.au/login?url=http://search.ebscohost.com/ $\underline{\text { login.aspx? } \text { direct }=\text { true } \& \mathrm{db}=\text { anh } \& A N=9258206}$ 9\&site $=$ eds-live

Aveling, H. (2007). Indonesian Literature after Reformasi: The Tongues of Women. Kritika Kultura, 8, 9-53. Retrieved from https://login. ezproxy.utas.edu.au/login?url=http://search. ebscohost.com/login.aspx?direct $=$ true $\& \mathrm{db}=\mathrm{eds}$ mzh\&AN=2007030840\&site $=$ eds-live

Comment: http://kritikakultura.ateneo.net/

Calderini, S. (2008). Islam and Diversity: Alternative Voices within Contemporary Islam. New Blackfriars, 89(1021), 324. Retrieved from https:// login.ezproxy.utas.edu.au/login?url=http:// search.ebscohost.com/login.aspx?direct=true \& $\mathrm{db}=\mathrm{edb} \& \mathrm{AN}=31678415 \&$ site $=$ eds-live

Creese, H. (2001). Ultimate Loyalties: The SelfImmolation of Women in Java and Bali. Bijdragen tot de Taal-, Land-en Volkenkunde, 157(1), 131-
166. Retrieved from https://login.ezproxy.utas. edu.au/login?url=http://search.ebscohost.com/ $\underline{\text { login.aspx} \text { ?direct }=\text { true } \& \mathrm{db}=\mathrm{edsmzh} \& \mathrm{AN}=200}$ 2421362\&site $=$ eds-live

Hamdani, D. (2007). The Quest for Indonesian Islam: Contestation and Consensus Concerning Veiling. (PhD), The National University of Australia, Australia.

Hammer, J. (2008). Identity, Authority, and Activism: American Muslim Women Approach the Qur'ān. Muslim World, 98(4), 443-464. doi:10.1111/ j.1478-1913.2008.00239.x

Hellwig, T. (2011). Abidah El Khalieqy's novels: Challenging patriarchal Islam, 16.

Heryanto, A. (2014). Identity and Pleasure The Politics of indonesian Screen Culture. Singapore: NUS Press.

Ismah, N. (2011). The New Generation of Women Writers from the Pesantren Tradition in Indonesia. Explorations, 11, 106-120.

Maryono, M. (2011). Ijtihad Al-Syaukani dalam Tafsir Fath Al-Qadir: Telaah atas Ayat-Ayat Poligami. Al-'Adalah, X(2).

Mustaqim, A. Pemikiran Fikih Kontemporer Muhamad Syahrur Tentang Poligami dan Jilbab.

Nilan, P., Demartoto, A., Broom, A., \& Germov, J. Indonesian Men's Perceptions of Violence Against Women.

Nurish, A. (2010). Women's Same-sex Relations in Indonesian Pesantren. Gender, Technology and Development, 14(2), 267-277.

Nurmila, N. (2007). Negotiating Polygamy in Indonesa: Between Muslim Discourse and Women's Lived Experiences. ( $\mathrm{PhD})$, University of Melbourne, Melbourne.

Osman, R. A. (2008). Defining Islamic Literature. International Journal of the Humanities, 5(11), 133-141. Retrieved from https://login.ezproxy. utas.edu.au/login?url=http://search.ebscohost. $\underline{\text { com} / \operatorname{login} . \text { aspx } ? \text { direct }=\text { true } \& \mathrm{db}=\mathrm{hlh} \& \mathrm{AN}=734}$ $\underline{66637 \& \text { site }=\text { eds-live }}$

Rohman, A. (2013). Reinterpret Polygamy in Islam: A Case Study in Indonesia. International Journal of Humanities and Social Science Invention, 2(10).

Ronaldo, R. (2011). Muslim Women, Moral Visions: Globalization and Gender Controversies in Indonesia. Springer Science +Business Media.

Sakai, M. (2012). Preaching to Muslim youth in Indonesia: the dakwah activities of Habiburrahman El Shirazy. RIMA: Review of Indonesian \& Malaysian Affairs, 46(1), 9-31. Retrieved from https://login.ezproxy.utas.edu. au/login?url=http://search.ebscohost.com/login. aspx?direct $=$ true $\& d b=$ anh \&AN $=92582079 \&$ si 
te $=$ eds-live

Smith, B. J. (2014). Sexual Desire, Piety, and Law in a Javanese Pesantren : Interpreting Varieties of Secret Divorce and Polygamy. Anthropological Forum, 24(3), 227. Retrieved from https://login. ezproxy.utas.edu.au/login?url=http://search. ebscohost.com/login.aspx?direct $=$ true $\& \mathrm{db}=\mathrm{edb}$ $\underline{\mathrm{AN}}=97983821 \&$ site $=$ eds-live

Stratton, A. (2005). A woman breaks a taboo. New Statesman, 134(4733), 12-12. Retrieved from https://login.ezproxy.utas.edu.au/ login?url=http://search.ebscohost.com/login.as px?direct $=$ true $\& d b=$ buh \& $A N=16502261 \&$ site =eds-live

van Wichelen, S. (2009). Polygamy talk and the politics of feminism: Contestations over masculinity in a new muslim Indonesia. Journal of International Women's Studies, 11(1), 173-188. Retrieved from https://login.ezproxy.utas.edu.au/ login?url=http://search.ebscohost.com/login.as px?direct $=$ true $\& \mathrm{db}=$ edselc $\& A N=$ edselc. $2-52.0$ $77952573687 \&$ site $=$ eds-live

Wadud, A. (1995). Towards a Qur'anic Hermeneutics of Social Justice: Race, Class and Gender, 37.

Wadud, A. (1999). Qur'an and Woman Rereading the
Sacred Text From a Women's Perspective London: Oxford University Press.

Wadud, A. (2006). Inside Gender Jihad Women's Reform in Islam. USA: The Maple-Vail Book Manufacturing Group.

Wadud, A. (2008). Engaging Tawhid in Islam and Feminism. International Feminist Journal of Politics.

Wartini, A. (2013). Poligami: Dari Fiqih Hingga Perundang-Undangan. Jurnal Studia Islamika, 10(2).

White, S. (2006). Gender and The Family. In G. Fealy \& V. Hooker (Eds.), Voices of Islam in Southeast Asia A Contemporary Sourcebook. Singapore: Intitute of Southeaast Asian Studies.

Wichelen, S. v. (2009). Polygamy Talk and the Politics of Feminism: Contestations over Masculinity in a New Muslim Indonesia. Journal of International Women's Studies, 11(1).

Wieringa, S. (1985). The Perfumed Nightmare: Some Notes on the Indonesian Women's Movement', Institute of Social Studies Sub-Series on Women's History and Development. 